\title{
Implementation of Learning Using Whatsap Based on A Scientific Approach to Improve Indonesian Learning Outcomes in Primary School Students
}

\author{
Slamet Hartanto \\ hartan.dunk@gmail.com
}

\section{Article History}

accepted 01/11/2020

approved 08/11/2020

published 15/11/2020

\begin{abstract}
This study aims to improve the learning outcomes of Indonesian class V SDN 2 Bendo using WhattsApp with a scientific approach. This research is a classroom action research with four main steps, namely: planning, acting, observing and reflecting. Collecting data in this study using observation and tests. The data collected was then analyzed and it can be concluded that the application of learning using Whatsapp based on a scientific approach can: (1) Improve the learning outcomes of class V students of SDN 2 Bendo, Nogosari District, Boyolali Regency, Semester I of the 2020/2021 academic year of $28.6 \%$ in pre cycle to $42.8 \%$ in cycle I, $71.4 \%$ in cycle II and in cycle III increased to 100\%. (2) The steps for implementing Whatsapp Social Media Based on the Scientific Approach can improve learning outcomes in Indonesian for Class V SDN 2 Bendo, Nogosari District, Boyolali Regency, Semester I of the 2020/2021 Academic Year. These steps include Observing, Asking, Trying, Reasoning, and Communicating.
\end{abstract}

Keywords: WhattsApp, scientific approach, learning outcomes

\begin{abstract}
Abstrak
Penelitian ini bertujuan untuk meningkatkan hasil belajar Bahasa Indonesia kelas V SDN 2 Bendo menggunakan WhattsApp dengan pendekatan saintifik. Penelitian ini adalah penelitian tindakan kelas dengan empat langkah utama yaitu: perencanaan, tindakan, pengamatan dan refleksi. Pengumpulan data pada penelitian ini menggunakan observasi dan tes. Data yang dikumpulkan kemudian dianalisis dan dapat disimpulkan bahwa penerapan pembelajaran menggunakan Whatsapp Berbasis Pendekatan Saintifik dapat: (1) Meningkakan hasil belajar Bahasa Indonesia peserta didik kelas V SDN 2 Bendo Kecamatan Nogosari Kabupaten Boyolali Semester I Tahun Ajaran 2020/2021 sebesar 28,6\% pada pra siklus menjadi 42,8\% pada siklus I, 71,4\% pada siklus II dan pada siklus III meningkat menjadi 100\%. (2) Langkah-langkah penerapan Media Sosial Whatsapp Berbasis Pendekatan Saintifik dapat meningkatkan hasil belajar Bahasa Indonesia Kelas V SDN 2 Bendo Kecamatan Nogosari Kabupaten Boyolali Semester I Tahun Ajaran 2020/2021. Langkah-langkah tersebut meliputi Mengamati, Menanya, Mencoba, Menalar, dan Mengkomunikasikan.
\end{abstract}

Kata kunci: WhattsApp, Pendekatan saintifik, Hasil Belajar

Social, Humanities, and Education Studies (SHEs): Conference Series https://jurnal.uns.ac.id/shes

p-ISSN 2620-9284

e-ISSN 2620-9292 


\section{PENDAHULUAN}

Virus Covid-19 berdampak pada perubahan pola pembelajaran di Indonesia. Meskipun proses belajar mengajar tatap muka diliburkan namun kegiatan belajar harus tetap berlangsung yakni melalui pembelajaran tanpa tatap muka dengan bantuan media teknologi yang dapat diakses dimana saja dan kapan saja. Media sosial merupakan media yang dapat digunakan sebagai sarana penyampaian materi serta berinteraksi antara guru dan peserta didik. Media sosial yang digunakan dalam penelitian ini menggunakan WhatsApp, Video Call dan youtube. Guru membentuk grup WhatsApp dalam satu kelas. Materi pembelajaran akan dikirim ke grup WhatsApp dan selanjutnya peserta didik akan melakukan diskusi di grup ini baik melalui chating ataupun video call.

Materi pembelajaran disajikan berbasis pemecahan masalah dengan pendekatan saintifik. Pendekatan saintifik merupakan salah satu pendekatan pembelajaran ilmiah. Daryanto (2014: 51) menyatakan bahwa pembelajaran dengan pendekatan saintifik merupakan proses pembelajaran yang dirancang sedemikian rupa agar peserta didik secara aktif mengkonstruksi konsep, hukum atau prinsip melalui tahapan-tahapan mengamati, merumuskan masalah, mengajukan atau merumuskan hipotesis, mengumpulkan data dengan berbagai teknik, menganalisis data, menarik kesimpulan dan mengkomunikasikan konsep, hukum atau prinsip yang ditemukan. Selanjutnya, Majid (2014: 193) menyatakan bahwa penerapan pendekatan saintifik bertujuan untuk pemahaman kepada peserta didik dalam mengenal, memahami berbagai materi menggunakan pendekatan ilmiah, bahwa informasi bisa berasal dari mana saja, kapan saja, tidak bergantung pada informasi searah dari guru.

Berdasarkan pengertian pendekatan saintifik di atas dapat disimpulkan bahwa pendekatan saintifik merupakan proses pembelajaran dimana peserta didik mengkonstruksi sendiri pengalaman belajarnya melalui kegiatan ilmiah yang meliputi mengamati (observing), menanya (questioning), mengumpulkan informasi/mencoba (experimenting), menalar/mengasosiasi, dan mengkomunikasikan (communicating).

Namun fenomena yang terjadi dilapangan masih jauh dari harapan. Hasil observasi yang dilakukan penulis di kelas V SDN 2 Bendo, kecamatan Nogosari, Kabupaten Boyolali pada tanggal 10 Oktober 2020 pada pembelajaran daring (dalam jaringan) menunjukkan bahwa guru hanya mengirimkan materi dalam buku teks setelah itu peserta didik diminta untuk mengerjakan LKS, guru tidak membuka forum diskusi secara formal sehingga peserta didik kurang aktif bertanya pada guru mengenai materi yang belum dipahami. Peserta didik hanya berorientasi pada tugas yang diberikan guru tanpa memahami konsep dari materi. Fenomena yang terjadi ini berdampak pada rendahnya hasil belajar siswa terutama pada muatan pelajaran Bahasa Indonesia. Dari 7 peserta didik hanya 2 peserta didik $(28,6 \%)$ tuntas KKM dan 5 peserta didik $(71,4 \%)$ belum tuntas KKM. Dikatakan tuntas KKM apabila peserta didik mencapai nilai $\geq 70$.

Berdasarkan permasalahan yang ada dapat disimpulkan bahwa akar permasalahannya adalah dalam proses pembelajaran guru belum menggunakan pendekatan yang tepat dimana siswa dapat mengkonstruksi sendiri pengetahuan melalui pengalaman belajar

Pendekatan pembelajaran yang sesuai dapat memngkonstruksi pengetahuan melalui pengalaman peserta didik adalah pendekatan saintifik. Hal ini sejalan dengan penerapan Kurikulum 2013 yang dicanangkan oleh pemerintah. Menurut Permendikbud Nomor 103 tahun 2014, proses pembelajaran terdiri atas lima pengalaman belajar pokok yaitu : 1) mengamati; 2) menanya; 3) mengumpulkan informasi/eksperimen; 4) mengasosiasikan/ mengolah informasi; dan 5) mengkomunikasikan. Selanjutnya, Nur Alamsyah (2016:82) menyatakan bahwa penerapan pendekatan saintifik merupakan suatu proses pembelajaran melalui pengamatan, bertanya, mencoba, kemudian menalar atau mengolah data informasi, 
menyajikan data atau informasi dilanjutkan dengan menganalisis, kemudian menyimpulkan. Dalam penelitian ini pendekatan saintifik akan diintegrasikan dengan media sosial WhatsApp.

WhatsApp adalah aplikasi yang digunakan oleh berbagai kalangan sebagai pengantar pesan yang sangat mudah digunakan, sederhana dan tentunya sangat canggih. WhatsApp ini digunakan sebagai media penyampaian materi dan komunikasi antara guru dan peserta didik dalam grup WhatsApp. Guru akan mengirim materi berupa video dan juga membuka forum diskusi melalui grup WhatsApp, sehingga apabila peserta didik mengalami kesulitan dapat didiskusikan di grup WhatsApp.

Keampuhan dari pendekatan Saintifik dalam meningkatkan hasil belajar telah terbukti hal ini ditunjukkan dari hasil penelitian yang telah dilakukan oleh Rahyuni, Zamzaili , Aceng Ruyani (2018) dengan berjudul Penerapan Pembelajaran Outdoor dengan Pendekatan Saintifik untuk Meningkatkan Hasil Belajar Siswa SMPN 6 Kota Bengkulu menunjukan bahwa Nilai rata-rata pretest dari siswa kelas eksperimen 62,1 setelah perlakuan rata-rata postingan siswa meningkat menjadi 86,25 yang berarti peningkatan 24,15 . Pada kelas kontrol skor rata-rata pretest 65,9 setelah pembelajaran konvensional meningkat menjadi 75,5 yang berarti terdapat peningkatan skor sebesar 9,6. Hasil belajar siswa yang menggunakan metode outdoor learning lebih tinggi daripada yang tidak menggunakan metode ini. Hal ini dilihat dari rata-rata nilai kelas eksperimen $(80,75)$ lebih besar dari kelas kontrol $(64,00)$ dengan peningkatan sebesar $26,37 \%$.

Berikutnya, keberhasilan media WhatsApp sebagai media dalam meningkatkan Hasil penelitian dari Pratama, H., \& Yusro, A. C. (2016) yang berjudul Implementasi WhatsApp mobile learning untuk meningkatkan hasil belajar mahasiswa pokok bahasan Pengenalan Komponen Elektronika. Hasil penelitian menunjukkan bahwa implementasi whatsapp sebagai mobile learning dapat meningkatkan hasil belajar mahasiswa pada pokok bahasan pengenalan komponen elektronika. Pada siklus I, pertemuan I ketercapaian pembelajaran sebesar $45 \%$ dan meningkat pada pertemuan II menjadi $60 \%$. Pada siklus II, ketercapaian pembelajaran juga meningkat pada pertemuan III menjadi $75 \%$ dan pertemuan IV sebesar $82 \%$.

Berdasarkan permasalahan yang ada dan kajian teori maka, penulis akan melakulan penelitian dengan judul Penerapan Pembelajaran Menggunakan Whatsapp Berbasis Pendekatan Saintifik Untuk Meningkatkan Hasil Belajar Bahasa Indonesia Pada Siswa Sekolah Dasar. Adapun rumusan masalah dalam penelitian ini adalah (1) Apakah Penerapan Pembelajaran Menggunakan Media Sosial Whatsapp Berbasis Pendekatan Saintifik Untuk Meningkatkan Hasil Belajar Bahasa Indonesia Kelas V SDN 2 Bendo Kecamatan Nogosari Kabupaten Boyolali Semester I Tahun Ajaran 2020/2021?. (2) Bagaimana Penerapan Pembelajaran Menggunakan media Sosial Whatsapp Berbasis Pendekatan Saintifik Untuk Meningkatkan Hasil Belajar Bahasa Indonesia Kelas V SDN 2 Bendo Kecamatan Nogosari Kabupaten Boyolali Semester I Tahun Ajaran 2020/2021?.

Sedangkan tujuannya adalah (1) untuk mengetahui Penerapan Pembelajaran Menggunakan Media Sosial Whatsapp Berbasis Pendekatan Saintifik Untuk Meningkatkan Hasil Belajar Bahasa Indonesia Kelas V SDN 2 Bendo Kecamatan Nogosari Kabupaten Boyolali Semester I Tahun Ajaran 2020/2021. (2) untuk mengetahui Langkah-langkah Penerapan Pembelajaran Menggunakan Media Sosial Whatsapp Berbasis Pendekatan Saintifik Untuk Meningkatkan Hasil Belajar Bahasa Indonesia Kelas V SDN 2 Bendo Kecamatan Nogosari Kabupaten Boyolali Semester I Tahun Ajaran 2020/2021.

\section{METODE}

Jenis penelitian, ini adalah Penelitian Tindakan Kelas (PTK) yang dilakukan di SDN 2 Bendo Kecamatan Nogosari, Kabupaten Boyolali pada kelas V dengan jumlah 7 peserta didik. Sumber data berasal dari studi dokumen dan observasi. Adapun teknik 
dan alat pengumpulan data yang digunakan adalah tes dan non tes, tes berupa evaluasi untuk mengetahui sejauh mana tingkat pemahaman peserta didik sedangkan non tes menggunkan lembar pengamatan guru dan peserta didik yang berguna untuk mengetahui pelaksanaan proses pembelajaran.

Tenik analisis data berupa data kuantitatif dan kualitatif. Data kuantitatif untuk mengetahui rata-rata hasil belajar dalam satu kelas sedangkan data kuantitatif berasal dari pengamatan guru dan peserta didik.

\section{HASIL DAN PEMBAHASAN}

Tabel 1 dan grafik 1 berikut menunjukkan hasil belajar Bahasa Indonesia dari pra siklus, siklus I, siklus II dan siklus III

Tabel 1

Perbandingan Hasil Belajar Bahasa Indonesia

Pra Siklus, Siklus I, Siklus II, Siklus III kelas V SDN 2 Bendo

\begin{tabular}{|c|c|c|c|c|c|c|c|c|c|}
\hline \multirow[b]{2}{*}{ No } & \multirow[b]{2}{*}{ Nilai } & \multicolumn{2}{|c|}{ Kondisi Awal } & \multicolumn{2}{|c|}{ Siklus I } & \multicolumn{2}{|c|}{ Siklus II } & \multicolumn{2}{|c|}{ Siklus III } \\
\hline & & $\mathbf{F}$ & $\begin{array}{c}\text { Persen } \\
\%\end{array}$ & $\mathbf{F}$ & $\begin{array}{c}\text { Perse } \\
\text { n } \\
\%\end{array}$ & $\mathbf{F}$ & $\begin{array}{c}\text { Persen } \\
\%\end{array}$ & $\mathbf{F}$ & $\begin{array}{c}\text { Perse } \\
\text { n } \\
\%\end{array}$ \\
\hline 1. & Tuntas & 2 & $28,6 \%$ & 3 & $42,8 \%$ & 5 & $71,4 \%$ & 7 & $100 \%$ \\
\hline 2. & Belum Tuntas & 5 & $71,4 \%$ & 4 & $57,1 \%$ & 2 & $28,6 \%$ & 0 & $0 \%$ \\
\hline & Jumlah & 7 & $100 \%$ & 7 & $100 \%$ & 7 & $100 \%$ & 7 & $100 \%$ \\
\hline
\end{tabular}

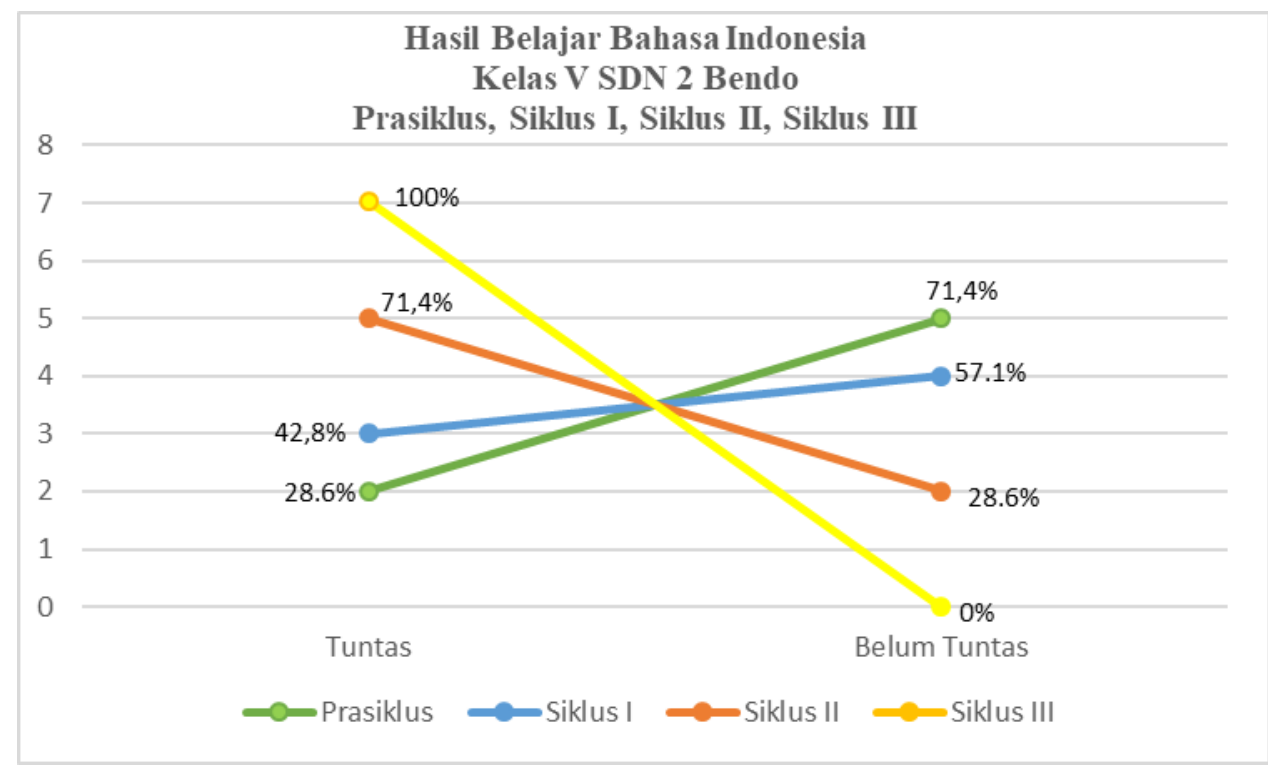

Grafik 1 Hasil Belajar Bahasa Indonesia Kelas V SDN 2 Bendo

Prasiklus, Siklus I, Siklus II, Siklus III

Berdasarkan tabel 1 dan grafik 1 mengenai perbandingan ketuntasan hasil belajar Bahasa Indonesia dapat dilihat peningkatan jumlah siswa yang mencapai KKM 70 pada muatan pelajaran Bahasa Indonesia Terbukti pada pra siklus terdapat masih banyak siswa yang belum mencapai KKM. Kemudian pada siklus I jumlah siswa yang mencapai ketuntasan meningkat menjadi 13 (42,8\%). Kemudian karena indikator keberhasilan belum tercapai maka dilakukan tindakan siklus II dengan hasil peningkatan yang cukup baik. Hal ini dapat dilihat pada siklus II jumlah siswa yang 
mencapai ketuntasan meningkat menjadi 5 (71,4\%). Selanjutnya, karena hasil belajar belum mencapai indikator keberhasilan maka dilakukan tindakan siklus III. Hasil belajar siklus III telah mencapai indikator keberhasilan yakni 7 peserta didik (100\%) telah mencapai nilai ketuntasan. Keberhasilan penerapan pembelajaran menggunakan whatsapp berbasis pendekatan saintifik dalam meningkatkan hasil belajar bahasa indonesia pada siswa sekolah dasar menjawab rumusan masalah yang pertama yaitu Apakah Penerapan Pembelajaran Menggunakan Media Sosial Whatsapp Berbasis Pendekatan Saintifik Untuk Meningkatkan Hasil Belajar Bahasa Indonesia Kelas V SDN 2 Bendo Kecamatan Nogosari Kabupaten Boyolali Semester I Tahun Ajaran 2020/2021.

Berikutnya, Efektivitas penerapan pembelajaran menggunakan Media Sosial Whatsapp Berbasis Pendekatan Saintifik dapat meningkatkan hasil belajar Bahasa Indonesia Kelas V dilakukan melalui langkah-langkah berikut; (1) mengamati, (2) menyanya, (3) mencoba, (4) menalar, (5) megkomunikasikan. Langkah pertama yaitu mengamati nampak saat peserta didik mengamati video pembelajaran dan gambar yang dikirimkan guru di WAG. Selanjutnya, langkah kedua, menanya tercermin pada saat peserta didik melakukan diskusi kelompok. Langkah ketiga yakni mencoba terlihat pada saat siswa mencoba membuat iklan Perilaku hidup sehat. Langkah keempat menalar nampak saat peserta didik menemukan kata kunci iklan. Sedangkan langkah kelima mengkomunikasikan terlihat saat peserta didik memperagakan iklan dan mengirimkan kepada guru. Keberhasilan penerapan pembelajaran ini menjawab rumusn masalah yang kedua yaitu Bagaimana Penerapan Pembelajaran Menggunakan Media Sosial Whatsapp Berbasis Pendekatan Saintifik Untuk Meningkatkan Hasil Belajar Bahasa Indonesia Kelas V SDN 2 Bendo Kecamatan Nogosari Kabupaten Boyolali Semester I Tahun Ajaran 2020/2021.

Keberhasilan dari pendekatan Saintifik dalam meningkatkan hasil belajar didukung oleh hasil penelitian pertama dari Nur Alamsyah (2016) dalam penelitiannya yang berjudul Penerapan Pendekatan Saintifik Untuk Meningkatkan Kreativitas dan Hasil Belajar Siswa Dalam Mata Pelajaran IPA menunjukkan bahwa terdapat peningkatan kreativitas dan hasil belajar siswa terhadap penerapan pendekatan saintifik. Kedua, Ulya, Fidya (2019) dalam penelitiannya yang berjudul Penerapan pendekatan saintifik berbantuan media gambar dan LKS untuk meningkatkan hasil belajar geografi pada kompetensi menganalisis jenis dan penanggulangan bencana alam siswa kelas XI IPS 2 SMAN Jogoroto Kabupaten Jombang menemukan enunjukkan bahwa dengan menerapkan pendekatan saintifik berbantuan media gambar dan LKS dapat meningkatkan hasil belajar geografi siswa kelas XI IPS 2 SMAN Jogoroto Kabupaten Jombang pada kompetensi jenis dan penanggulangan bencana alam. Rata-rata hasil belajar geografi pada siklus 1 ke siklus 2 mengalami peningkatan sebesar $19,61 \%(10,59)$ menjadi 64,59 .

Keberhasilan dari implementasi WhatsApp dalam meningkatkan hasil belajar didukung oleh hasil penelitian pertama dari Pratama, H., \& Yusro, A. C. (2016) yang berjudul Implementasi WhatsApp mobile learning untuk meningkatkan hasil belajar mahasiswa pokok bahasan Pengenalan Komponen Elektronika. Hasil penelitian menunjukkan bahwa implementasi whatsapp sebagai mobile learning dapat meningkatkan hasil belajar mahasiswa pada pokok bahasan pengenalan komponen elektronika. Pada siklus I, pertemuan I ketercapaian pembelajaran sebesar $45 \%$ dan meningkat pada pertemuan II menjadi $60 \%$. Pada siklus II, ketercapaian pembelajaran juga meningkat pada pertemuan III menjadi $75 \%$ dan pertemuan IV sebesar $82 \%$. Kedua, Utomo, S. W., \& Ubaidillah, M. (2018) Pemanfaatan Aplikasi Whatsapp pada Pembelajaran Berbasis Masalah untuk Mata Kuliah Akuntansi Internasional di Universitas PGRI Madiun. Hasil penelitian menunjukkan bahwa penerapan model pembelajaran berbasis masalah dengan pemanfaatan aplikasi Whatsapp berpengaruh atau berdampak positif terhadap hasil belajar mahasiswa. Hasil belajar yang diperoleh 
mahasiswa secara keseluruhan (32 mahasiswa) adalah nilai 77 sampai 97 di atas kriteria capaian yang ditetapkan nilai 71 . Mahasiswa lebih mudah berkomunikasi, berkoordinasi, dan berdiskusi sebelum melakukan presentasi tanpa harus bertemu secara langsung. Ketiga, Hilwa Putri Kamil (2019) dalam penelitiannya yang berjudul Pengaruh Pemanfaatan Media Sosial Whatsapp Terhadap Motivasi Belajar Bahasa Indonesia di SMP Islam AI Wahab Jakarta Tahun Pelajaran 2018/2019 menunjukkan pemanfaatan media sosial whatsApp termasuk kategori media sosial yang bermanfaat untuk media belajar untuk informasi dan diskusi masalah pelajaran. Jika diinterpretasikan pemanfaatan media sosial whatsApp termasuk ke dalam kategori hubungan positif yang jika diinterpretasikan dalam tabel skala Likert maka pemanfaatan media sosial whatsApp siswa SMP Islam AI Wahab Jakarta termasuk ke dalam kategori media sosial whatsApp yang setuju menunjukan pemanfaatan dalam media diskusi dan informasi dalam kegiatan belajar. Adapun pengaruh dari pemanfaatan media sosial whatsApp terhadap motivasi belajar bahasa Indonesia siswa sebesar $25,2 \%$, sedangkan $74,8 \%$ ditentukan oleh faktor lainnya, seperti faktor lingkungan belajar, faktor keluarga, faktor kecerdasan siswa, serta beberapa faktor lain baik dari dalam diri siswa maupun dari luar.

Keunggulan dalam penelitian ini dibandingkan dengan penelitian lainnya, yaitu dalam penelitian ini menggunakan Media Sosial Whatsapp Berbasis Pendekatan Saintifik dalam meningkatkan hasil belajar peserta didik.

\section{SIMPULAN}

Berdasarkan hasil penelitian dan pembahasan, dapat disimpulkan bahwa penerapan pembelajaran menggunakan Whatsapp Berbasis Pendekatan Saintifik dapat:

a) Meningkakan hasil belajar Bahasa Indonesia peserta didik kelas V SDN 2 Bendo Kecamatan Nogosari Kabupaten Boyolali Semester I Tahun Ajaran 2020/2021 sebesar $28,6 \%$ pada pra siklus menjadi $42,8 \%$ pada siklus I, $71,4 \%$ pada siklus II dan pada siklus III meningkat menjadi $100 \%$.

b) Pelaksanaan penerapan langkah-langkah menggunakan Media Sosial Whatsapp Berbasis Pendekatan Saintifik dapat meningkatkan hasil belajar Bahasa Indonesia Kelas V SDN 2 Bendo Kecamatan Nogosari Kabupaten Boyolali Semester I Tahun Ajaran 2020/2021. Langkah-langkah tersebut meliputi Mengamati, Menanya, Mencoba, Menalar, dan Mengkomunikasikan.

Impilkasi

1) Pemilihan metode/pendekatan pembelajaran yang tepat dapat berpengaruh terhadap pencapaian hasil belajar peserta didik.

2) Sebagai masukan bagi guru untuk membenahi diri sehubungan dengan pengajaran yang telah dilakukan dan hasil belajar peserta didik yang telah dicapai dengan memperhatikan metode/pendekatan pembelajaran yang tepat untuk meningkatkan hasil belajar peserta didik.

\section{Rekomendasi}

1) Bagi guru, hendaknya guru menggunakan Media Sosial Whatsapp Berbasis Pendekatan Saintifik. Dalam meningkatkan hasil belajar peserta didik.

2) Bagi Kepala Sekolah, hendaknya kepala sekolah mau mendorong guru untuk berpartisipasi aktif dalam setiap penelitian tindakan kelas yang dilaksanakan guru lain serta ikut membantu pelaksanaan penelitian tindakan kelas tersebut.

\section{DAFTAR PUSTAKA}

Alamsyah, N. (2016). Penerapan Pendekatan Saintifik untuk Meningkatkan Kreativitas dan Hasil Belajar Siswa dalam Mata Pelajaran IPA. JP (Jurnal Pendidikan): Teori dan Praktik, 1(1), 82-96.

Daryanto. 2014. Pendekatan Saintifik Kurikulum 2013. Yogyakarta: Gava Media 
Hilwa Putri Kamil (2019) dalam penelitiannya yang berjudul Pengaruh Pemanfaatan Media Sosial Whatsapp Terhadap Motivasi Belajar Bahasa Indonesia di Smp Islam Al Wahab Jakarta Tahun Pelajaran 2018/2019. Jakarta: Fakultas IImu Tarbiyah Dan Keguruan UIN Syarif Hidayatullah.

Majid, Abdul. (2014). Pembelajaran Tematik Terpadu. Bandung: Remaja Rosdakarya

Permendikbud Nomor 103 Tahun 2014 tentang Pembelajaran Pendidikan Dasar dan Pendidikan Menengah

Pratama, H., \& Yusro, A. C. (2016). Implementasi WhatsApp mobile learning untuk meningkatkan hasil belajar mahasiswa pokok bahasan Pengenalan Komponen Elektronika. Jurnal Pendidikan Fisika dan Keilmuan (JPFK), 2(2), 65-69

Rahyuni, R., Zamzaili, Z., \& Ruyani, A. (2018). Penerapan Pembelajaran Outdoor dengan Pendekatan Saintifik untuk Meningkatkan Hasil Belajar Siswa SMPN 6 Kota Bengkulu. PENDIPA Journal of Science Education, 2(3), 183-187.

Utomo, S. W., \& Ubaidillah, M. (2018). Pemanfaatan Aplikasi Whatsapp pada Pembelajaran Berbasis Masalah untuk Mata Kuliah Akuntansi Internasional di Universitas PGRI Madiun. Kwangsan, 6(2). 